
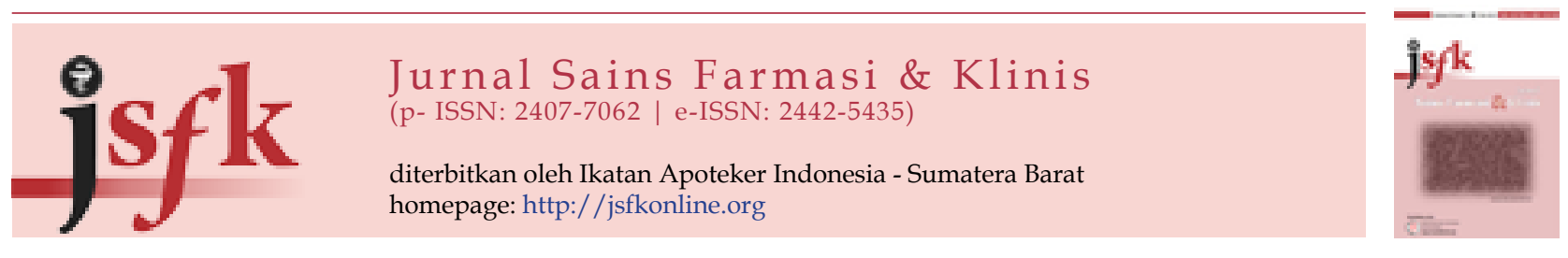

\title{
Senyawa Antibiotik dari Bacillus sp1 (HA1) yang Bersimbiosis pada Spon Laut Haliclona fascigera
}

(Antibiotic compound of symbiotic Bacillus sp1 (HA 1) from marine sponge Haliclona fascigera)

\author{
Wiza Leila Puspita Sari, Deddi Prima Putra, \& Dian Handayani*
}

Fakultas Farmasi Universitas Andalas

\begin{abstract}
Keywords:
symbiotic bacteria;

Bacillus sp.; antibacterial activity; marine sponge;

Haliclona fascigera.
\end{abstract}

Kata Kunci:

bakteri simbion;

Bacillus sp.; aktivitas antibakteri; spon laut;

Haliclona fascigera.

\begin{abstract}
Symbiotic bacteria are bacteria that live within a host tissue and do not harm the host itself. These bacteria can produce various bioactive compounds such as antibacterial compounds. This study aimed to isolate the antibiotic compounds from ethyl acetate extract of symbiotic bacteria Bacillus sp.1 (HA1) of marine sponge Haliclona fascigera. Bacterial cultivation was performed on Nutrient Broth medium using incubator shaker at $150 \mathrm{rpm}$ at $37^{\circ} \mathrm{C}$ for 24 hours. The isolation of antibiotic compound was done by column chromatography method and testing of antibacterial activity was conducted by agar diffusion method. The study revealed 2 pure compounds $W_{1}$ and $W_{2}$. The compound $W_{1}(10.8 \mathrm{mg})$ was soluble in the ethyl acetate and methanol but was difficult to dissolve in n-hexane. This compound could inhibit the growth of pathogenic bacteria Staphylococcus aureus ATCC 25923 with 1\% of minimum inhibition concentration (MIC). While the compound W2 $(2.3 \mathrm{mg})$ was soluble in dichloromethane and methanol but was difficult to dissolve in n-hexane. The W2 compound could not inhibit the growth of Staphylococcus aureus ATCC 25923.
\end{abstract}

ABSTRAK: Bakteri simbion merupakan bakteri yang hidup dalam jaringan suatu host dan tidak merugikan host tersebut. Bakteri ini dapat menghasilkan berbagai senyawa bioaktif seperti antibakteri. Penelitian ini bertujuan untuk mengisolasi senyawa antibiotik dari ekstrak etil asetat bakteri Bacillus sp1 (HA1) yang bersimbiosis dengan spon laut Haliclona fascigera. Metoda yang digunakan yaitu kultivasi bakteri pada media Nutrient Broth menggunakan Incubator Shaker dengan kecepatan $150 \mathrm{RPM}$ pada suhu $37^{\circ} \mathrm{C}$ selama $24 \mathrm{jam}$. Isolasi senyawa antibakteri dilakukan dengan metoda kromatografi kolom dan pengujian aktivitas antibakteri dengan metode difusi agar. Dari penelitian yang telah dilakukan diperoleh 2 senyawa antibakteri W 1 dan W2. Senyawa W1 (10,8 mg) larut dalam pelarut etil asetat dan metanol, tapi sukar larut dalam n-heksana. Senyawa ini dapat menghambat pertumbuhan bakteri patogen Staphylococcus aureus ATCC 25923 dengan Konsentrasi Hambat Minimum (KHM) 1\%. Sedangkan senyawa W2 (2,3 mg) larut dalam diklorometana dan metanol, namun sukar larut dalam n-heksana. Senyawa W2 tidak dapat menghambat pertumbuhan Staphylococcus aureus ATCC 25923.

\section{PENDAHULUAN}

Penyakit infeksi telah menjadi penyebab utama untuk morbiditas dan mortalitas manusia, bersamaan dengan penyakit non infeksi lainnya seperti penyakit kanker. The Global Burden of
Disease Study (GDBS) memperkirakan bahwa pada tahun 2015, penyakit infeksi merupakan salah satu dari 10 penyebab kematian terbesar di dunia [1].

Berbagai macam antibiotik sintetik telah dikembangkan untuk melawan penyakit infeksi yang disebabkan oleh bakteri, akan tetapi
*Corresponding Author: Dian Handayani (Fakultas Farmasi Universitas Andalas, Kampus Limau Manis, Kec. Pauh, Padang 25163, Sumatera Barat, Indonesia) email: dianh_17@yahoo.com
Article History:

Received: 27 Apr 2017

Published: 16 May 2017
Accepted: 07 May 2017

Available online: 30 May 2017 
penggunaan antibiotik sintetik kadang-kadang memberikan efek samping yang tidak diinginkan terhadap tubuh [2], sehingga perlu dilakukan penelitian untuk mengembangkan antibiotik baru dari bahan alam [3].

Hasil studi literatur menunjukkan bahwa makroorganisme laut, seperti spon atau ganggang, merupakan sumber yang kaya akan senyawa aktif biologis [4,5]. Selama periode 2000-2005, sekitar 100 metabolit makroorganisme laut telah diklasifikasikan [6]. Pada periode 2006 sampai pertengahan 2010 ditemukan 690 produk alami yang diisolasi dari habitat laut [7]. Dalam beberapa tahun terakhir, banyak senyawa bioaktif telah diekstraksi dari berbagai hewan laut seperti tunikata, spon, karang lunak, siput laut dan mikroorganisme laut [8].

Baru-baru ini, banyak penelitian yang melaporkan bahwa senyawa-senyawa bioaktif yang berasal dari invertebrata laut memiliki kemiripan dengan metabolit yang dihasilkan oleh mikroorganisme simbionnya, seperti jamur dan bakteri [9]. Mikroorganisme simbion diduga adalah produsen asli dari senyawa bioaktif pada spon [10]. Bukti eksperimental pertama yang mendukung hipotesis ini berasal dari penelitian Faulkner [11], yang menyelidiki lokalisasi produk bahan alam dari mikroorganisme simbion pada spon.

Jenis senyawa metabolit sekunder yang berhasil diisolasi dari bakteri yang bersimbiosis dengan spon memperlihatkan kuantitas yang lebih banyak dari mikroorganisme laut lainnya. Hal ini terutama dikarenakan kemudahan dalam kultur massalnya [12].

Hasil skrining dari penelitian sebelumnya menunjukkan bahwa 16 isolat bakteri simbion yang aktif terhadap Staphylococcus aureus, Escherichia coli, dan Candida albicans. Isolat bakteri yang memiliki aktivitas paling baik ditunjukkan dengan daya hambat yang besar adalah isolat bakteri
HA1, H1RE1, A1 dan C1 yang masing-masing telah diidentifikasi sebagai bakteri Bacillus sp. dan Staphylococcus sp. Isolat bakteri HA1, H1RE1, A 1 dan $\mathrm{C} 1$ aktif menghambat bakteri uji $S$. aureus, sedangkan isolat bakteri A1 aktif terhadap kedua bakteri uji S. aureus dan E. coli [13]. Tulisan ini merupakan penelitian lanjutan untuk mengisolasi dan karakterisasi awal senyawa antibiotic dari isolat Bacillus sp1 (HA1), simbion dari Haliclona fascigera.

\section{METODE PENELITIAN}

Bakteri Simbion Bacillus sp1 (HA1) dari Spon Laut Haliclona fascigera

Isolat bakteri simbion Bacillus spl (HA1) dari Spon Laut Haliclona fascigera diperoleh dari peneliti sebelumnya [13].

Penentuan Waktu Kultivasi Optimum Isolat Bacillus sp1 (HA 1)

Penentuan waktu kultivasi optimum bertujuan untuk menentukan waktu yang tepat dalam memperoleh kultur bakteri tersebut secara maksimal. Satu ose koloni Bacillus sp1 (HA1) diinokulasikan dalam $100 \mathrm{~mL}$ medium Nutrient Broth $\left(\right.$ Merck $\left.^{\circledR}\right)$, Bakteri kemudian dikultivasi dengan alat Incubator Shaker Series pada suhu $37^{\circ} \mathrm{C}$ dengan kecepatan 150 RPM selama 96 jam. Setiap 0, 24, 30, 48, 72, dan 96 jam waktu inkubasi, Optical Density (OD) media fermentasi diukur dengan menggunakan spektrofotometer UV-VIS Pharmaspec $1700 \quad\left(\right.$ Shimadzu $\left.^{\circledR}\right)$, pada panjang gelombang $600 \mathrm{~nm}$. Data pengukuran pertumbuhan media tersebut digambarkan sebagai kurva pertumbuhan isolat bakteri.

Kultivasi Isolat Bacillus sp1 (HA1)

Satu ose kultur Bacillus spl (HA1) diinokulasikan dalam media NB sebanyak 7 L. Kemudian diinkubasi dengan alat Incubator Shaker Series dengan kecepatan 150 RPM pada suhu $37^{\circ} \mathrm{C}$ 
selama waktu kultivasi optimum.

Ekstraksi Senyawa Metabolit Sekunder Isolat Bacillus sp1 (HA 1)

Kultur bakteri Bacillus sp1 (HA1) sebanyak $7 \mathrm{~L}$ dimaserasi dengan pelarut etil asetat perbandingan 1:1 selama 3 hari. Hasil ekstraksi disonikasi selama 5 menit. Pemisahan ekstrak dari medium kultur menggunakan corong pisah. Kemudian pelarut diuapkan dengan rotary evaporator $\left(\right.$ Buchi $\left.^{\circledR}\right)$, sehingga didapatkan ekstrak kental etil asetat sebanyak $1.02 \mathrm{~g}$.

\section{Isolasi dan Pemurnian Senyawa Antibiotik}

Sebelum dilakukan pemisahan, dilakukan pemonitoran penyebaran noda pada Kromatografi Lapis Tipis (KLT) $\left(\right.$ Merck $\left.^{\circledR}\right)$, ekstrak etil asetat ini memperlihatkan pola pemisahan noda yang baik dengan menggunakan fasa gerak etil asetat : metanol: asam asetat glacial (19:1:0.1). Selanjutnya ekstrak sebanyak $1.02 \mathrm{~g}$ dikromatografi kolom menggunakan fasa diam silika gel $60(0,2-0,5 \mathrm{~mm})$ $\left(\right.$ Merck $\left.^{\circledR}\right)$, dan fasa gerak etil asetat:metanol:asam asetat glasial dengan perbandingan 19:1:0.1 secara isokratik. Fraksi dengan pola noda yang sama kemudian digabung sehingga diperoleh 3 fraksi yaitu fraksi 1 (276.3 mg), 2 (91.7 mg), dan 3 (216.4 mg). Tiga fraksi yang didapatkan dilakukan pengujian aktivitas antibakteri dengan metode difusi agar dan fraksi 3 memberikan zona bening yang paling besar di sekeliling cakram. Pemisahan senyawa fraksi 3 dilakukan dengan kromatografi kolom dengan menggunakan komposisi fasa gerak yang sama yaitu etil asetat:metanol:asam asetat glacial (9:1:0.1). Fraksi kolom tersebut ditampung dalam vial dan fraksi dengan noda yang sama digabung. Diperoleh fraksi 3A (21 mg), 3B (13.7 $\mathrm{mg}), 3 \mathrm{C}(3.2 \mathrm{mg}), 3 \mathrm{D}(12.4 \mathrm{mg})$, dan $3 \mathrm{E}(5.1 \mathrm{mg})$. Dari hasil uji aktivitas antibiotik dari kelima cakram, fraksi 3B menunjukkan adanya aktivitas antibakteri dimana terdapat zona bening di sekeliling cakram. Dari hasil monitoring dengan menggunakan KLT, fraksi $3 \mathrm{~B}$ memberikan pola noda yang mirip dengan fraksi $3 \mathrm{~A}$ dan $3 \mathrm{C}$, sehingga ketiga fraksi tersebut digabung dan dilanjutkan dengan pengisolasian senyawa murni antibakteri.

Pada penelitian ini juga dilakukan pemisahan kandungan kimia lainnya dari fraksi 1. Dari fraksi ini dilakukan kromatografi kolom dengan cara yang sama menggunakan metode isokratik dengan fasa gerak n-heksan:etil asetat (4:1). Hasil kromatografi kolom kemudian dimonitoring dengan menggunakan dan didapatkan 6 fraksi yang belum menunjukkan satu noda sehingga pemisahan dilanjutkan dengan menggunakan Kromatografi Lapis Tipis Preparatif menggunakan plat dari lempeng kaca berukuran 20x20 $\mathrm{cm}$ dengan pengelusi larutan n-heksana:etil asetat (4:1).

\section{Uji Aktivitas Antibiotik}

Sebelum dilakukan pengujian aktivitas antibakteri, media Nutrient Agar (NA) (Merck ${ }^{\circledR}$ ), yang telah memadat telah disiapkan dan pembuatan suspensi Staphylococcus aureus ATCC 25923. Sebanyak 0,1 ml (100 $\mu \mathrm{l})$ suspensi bakteri uji dimasukkan ke dalam media NA dan diswab menggunakan cotton bud steril. Sejumlah konsentrasi uji (2\%; $1 \%$; $0.5 \%$; $0.25 \%$ ) dari senyawa hasil isolasi diteteskan pada kertas cakram steril $\left(\right.$ Advantec $\left.^{\circledR}\right)$, dan diletakkan di atas permukaan medium. Inkubasi menggunakan inkubator $\left(\right.$ Galenkamp plus ${ }^{\circledR}$ ), pada suhu $37^{\circ} \mathrm{C}$ selama 24 jam. Setelah diinkubasi dilihat apakah terdapat zona bening disekitar kertas cakram. Zona bening yang dihasilkan diukur menggunakan jangka sorong. Sebagai kontrol negatif digunakan pelarut etil asetat dan sebagai kontrol positif digunakan antibiotik kloramfenikol konsentrasi $0.3 \%$ $\left(\right.$ Sigma $\left.^{\circledR}\right)$. 


\section{HASIL DAN DISKUSI}

Dari hasil penelusuran literatur dilaporkan bahwa spon merupakan host dari mikroorganisme laut seperti bakteri dan jamur. Bakteri genus Bacillus yang bersimbiosis dengan spon laut mampu menghasilkan senyawa-senyawa metabolit sekunder yang memiliki bioaktivitas. Sebagai contoh, Bacillus vallismortis, bakteri yang bersimbiosis dengan spon Dysidea avara menghasilkan senyawa Neobacillamide A dan Bacillamide C. Kedua senyawa ini diketahui memiliki aktivitas menghambat pertumbuhan ganggang merah [14].

Penentuan waktu kultivasi optimum Bacillus sp1 (HA 1)

Berdasarkan hasil pengujian waktu kultivasi optimum diketahui bahwa bakteri Bacillus sp1 (HA1) tumbuh maksimal pada waktu 24 jam kultivasi (gambar 1). Dari hasil kultivasi Bacillus sp1 (HA1) sebanyak $7 \mathrm{~L}$ diperoleh ekstrak kering etil asetat sebanyak $1.02 \mathrm{~g}$.
Isolasi dan Karakterisasi Senyawa Metabolit Sekunder Bacillus sp1 (HA1)

Hasil pemisahan dengan kromatografi kolom didapatkan 3 fraksi yang dilanjutkan dengan pengujian aktivitas antibakteri. Fraksi 3 mempunyai Konsentrasi Hambat Minimum 1\% terhadap bakteri S. aureus ATCC 25923 dengan diameter hambat rata-rata $8 \mathrm{~mm}$. Fraksi 3 (216,4 mg) dipisahkan dengan kromatografi kolom sehingga didapatkan 5 fraksi (3A-E) yang dilanjutkan uji aktivitas antibakteri. Dari hasil uji aktivitas antibakteri dari kelima fraksi ini, fraksi 3B menunjukkan adanya aktivitas antibakteri dimana terdapat zona bening di sekeliling cakram. Dari hasil monitoring dengan menggunakan KLT, fraksi 3A dan 3C memberikan pola noda yang sama dan kemudian digabung sehingga diperoleh fraksi $3 \mathrm{X}$ (37.9 mg). Fraksi 3X kemudian dilakukan isolasi senyawa kembali menggunakan kromatografi kolom dengan fasa diam silica gel sehingga diperoleh fraksi 3X-1 (24.7 mg), 3X-2 (3.5 mg) dan 3X-3 (3.1 mg). Hasil isolasi didapatkan senyawa W1 (10.8 mg) yang telah menunjukkan satu noda

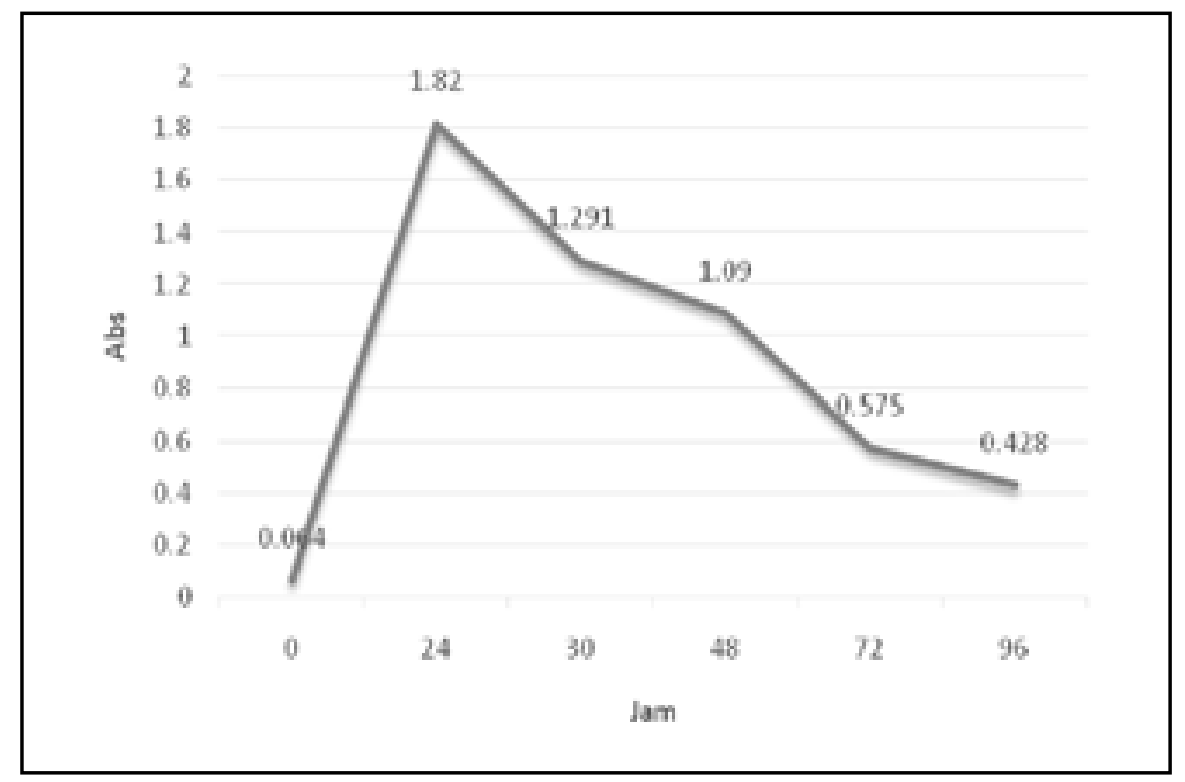

Gambar 1. Kurva optimasi waktu pertumbuhan Bacillus sp.1 (HA1) 


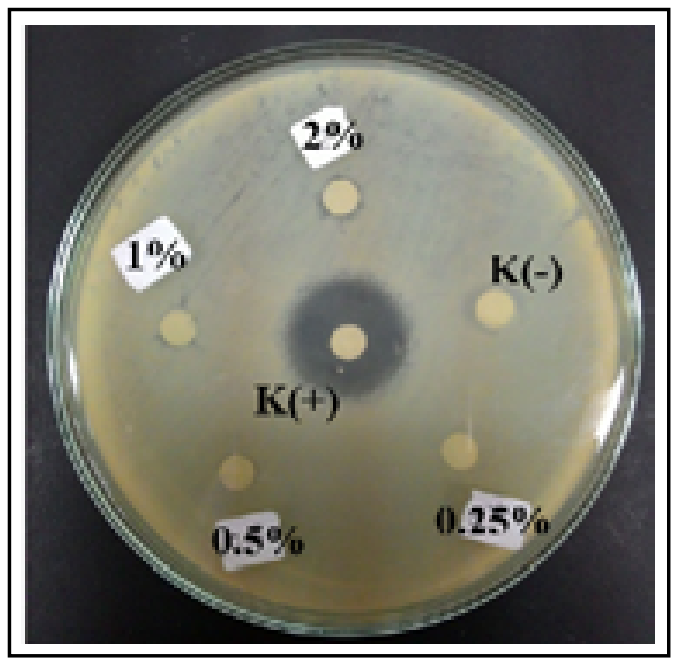

Gambar 2. Hasil uji aktivitas antibiotik

senyawa W1 terhadap S. aureus ATCC 25923

saat dimonitoring menggunakan KLT dibawah penampak noda sinar UV254nm dan uap iodium.

Senyawa murni W1 mempunyai Rf 0,75 dengan fasa gerak kloroform:metanol:asam asetat glacial (9:0,5:0,5). Senyawa ini berupa minyak semi solid bewarna kuning dan berbau khas, dan larut dalam etil asetat.

Pada pengujian aktivitas antibiotik, senyawa W1 memberikan aktivitas antibiotik terhadap bakteri uji S. aureus ATCC 25923 pada konsentrasi 2\% dengan diameter hambat $8 \mathrm{~mm}$ (gambar 2). Konsentrasi Hambat Minimum (KHM) senyawa W1 terhadap bakteri $S$. aureus ATCC 25923 adalah 1\% dengan diameter hambat $7 \mathrm{~mm}$.

Pemeriksaan kimia terhadap senyawa W1 dengan menggunakan pereaksi Dragendorff dan $\mathrm{FeCl}_{3}$ menunjukkan reaksi negatif, tetapi dengan pereaksi uap iodium menghasilkan noda berwarna kuning-jingga. Spektrum UV senyawa W1 dalam pelarut metanol memperlihatkan serapan maksimum pada panjang gelombang 264,20 $n m \quad(A b s=0,202)$. Pemeriksaan menggunakan spektrofotemer inframerah tidak dapat dilakukan pada senyawa W1 karena jumlahnya sangat sedikit.

Dari fraksi lain juga diperoleh senyawa murni W2 (2,3 mg) dengan nilai Rf 0,51 setelah dieluasi dengan fasa gerak n-heksana:etil asetat (4:1). Senyawa ini berupa minyak berwarna merah bata yang larut dalam metanol dan dikloromethana. Senyawa W2 tidak bereaksi dengan pereaksi Dragendorff dan $\mathrm{FeCl}_{3}$.

Spektrum UV senyawa W2 dalam pelarut metanol memperlihatkan serapan maksimum pada panjang gelombang 341,00 nm (Abs=0,433);

Tabel 1. Hasil pemeriksaan aktivitas antibiotik senyawa W1 terhadap bakteri S. aureus ATCC 25923

\begin{tabular}{|c|c|c|c|}
\hline Konsentrasi (\%) & $\begin{array}{l}\text { Diameter Hambat } \\
\text { ( } \mathrm{mm})\end{array}$ & $\begin{array}{c}\text { Diameter Hambat } \\
\text { Pembanding }(\mathrm{K}+) \\
\text { Kloramfenikol } 0,3 \%(\mathrm{~mm})\end{array}$ & $\begin{array}{c}\text { Diameter Hambat } \\
\text { Pembanding }\left(\mathrm{K}^{-}\right)(\mathrm{mm})\end{array}$ \\
\hline 2 & 8 & \multirow{4}{*}{19} & \multirow{4}{*}{-} \\
\hline 1 & 7 & & \\
\hline 0,5 & - & & \\
\hline 0,25 & - & & \\
\hline
\end{tabular}


Tabel 2. Karakterisasi senyawa W1 dan W2

\begin{tabular}{|c|c|c|c|}
\hline No & Karakterisasi & Senyawa $W 1$ & Senyawa $W_{2}$ \\
\hline \multirow[t]{3}{*}{1.} & Organoleptis & & \\
\hline & - Bentuk & Minyak semi solid & Minyak semi solid \\
\hline & - Warna & Kuning & Merah bata \\
\hline \multirow[t]{2}{*}{2.} & Pemeriksaan fisika & & \\
\hline & - Kelarutan & Larut dalam etil asetat & $\begin{array}{l}\text { Larut dalam dikloromethana dan } \\
\text { methanol }\end{array}$ \\
\hline \multirow[t]{4}{*}{3.} & Pemeriksaan Senyawa Kimia & & \\
\hline & - Dragendorff & Tidak Bereaksi & Tidak bereaksi \\
\hline & - $\mathrm{FeCl}_{3}$ & Tidak Bereaksi & Tidak bereaksi \\
\hline & - Uap Kristal Iodium & Kuning-Jingga & - \\
\hline 4. & $\begin{array}{l}\text { Pemeriksaan Kromatografi } \\
\text { lapis Tipis (KLT) }\end{array}$ & $\begin{array}{l}\text { Fasa Gerak kloroform: } \\
\text { methanol : asam asetat } \\
\text { glacial }(9: 0,5: 0,5) \mathrm{Rf}=0,75\end{array}$ & $\begin{array}{l}\text { Fasa Gerak n-heksana:etil asetat } \\
(3: 2) \mathrm{Rf}=0,51\end{array}$ \\
\hline
\end{tabular}

244,20 nm (Abs=0,105); dan 202,00 nm $($ Abs=0,522). Dari hasil pemeriksaan spektrum IR dengan alat Spektrofotometer Fourtier Transform InfraRed (FT-IR) Spectrum One (Perklin Elmer ${ }^{\circledR}$ ), senyawa W2 menunjukkan serapan kuat pada bilangan gelombang 3422,79 $\mathrm{cm}^{-1}$ yang diduga diberikan oleh gugus OH. Serapan pada bilangan gelombang 2923,47 $\mathrm{cm}^{-1}-2853,73 \mathrm{~cm}^{-1}$ diduga disebabkan adanya regangan $\mathrm{C}-\mathrm{H}$ alifatis. Absorpsi pada 1637,19 $\mathrm{cm}^{-1}$ merupakan absorpsi karakteristik dari regang $\mathrm{C}=\mathrm{O}$. Namun pada pengujian aktivitas antibiotik, senyawa $\mathrm{W} 2$ tidak menunjukan aktivitas antibakteri terhadap bakteri uji S. aureus ATCC 25923.

Pada hasil penelitian sebelumnya, ekstrak isolat bakteri Bacillus sp1 (HA1) memiliki aktivitas antibakteri dengan diameter hambat $24 \mathrm{~mm}$ pada konsentrasi 1\% terhadap S. aureus [13]. Namun aktivitas antibakteri tersebut menurun setelah ekstrak difraksinasi dan dimurnikan. Hal ini diduga disebabkan karena perbedaan faktor nutrisi, lingkungan ataupun faktor genetik yang terjadi pada bakteri simbion. Setelah bakteri Bacillus sp1 (HA1) diisolasi dari spon laut Haliclona fascigera, telah lebih dari 25 kali dilakukan peremajaan terhadap bakteri Bacillus sp1 (HA1) dalam medium Nutrient Agar (NA). Kemungkinan bakteri-bakteri tersebut mengharuskan adanya perantara sistem metabolisme dari spon sebagai inangnya. Adapula beberapa isolat bakteri yang belum diketahui alasannya berhenti menghasilkan produk-produk senyawa bioaktif setelah dikulturkan beberapa waktu pada media buatan. Ini diduga karena adanya keterlibatan faktor genetik, dimana gen yang menyajikan senyawa bioaktif tersebut hilang akibat mutasi atau hilangnya faktor penggerak elemen-elemen genetik yang mensintesis gen-gen tersebut [15].

\section{KESIMPULAN}

Bakteri yang bersimbiosis dengan spon laut potensial untuk menghasilkan senyawa antibiotik baru dalam menghadapi permasalahan dalam resistensi antibiotik yang tengah berkembang saat ini. Pada penelitian ini telah diisolasi senyawa $\mathrm{W} 1$ yang memiliki aktivitas sebagai antibiotik terhadap bakteri uji Staphylococcus aureus ATCC 25923. 


\section{DAFTAR PUSTAKA}

1. World Health Organization. (2017). The top 10 causes of the death. Geneva.

2. Aliero, A., Aliero, B. L., \& Buhari, U. (2008). Preliminary phytochemical and antibacterial screening of Scadoxus multiflorus. Int J Pure Appl Sci, 2(4), 13-17.

3. Andayani, S. G. D., Linar, Z. U., Kardono, L. B. S., \& Hanafi, M. (2006). Antibotika baru dari Actinomycetes dan Jamur. Prosiding Seminar Nasional Himpunan Kimia Indonesia. Departemen Kimia FMIPA IPB.

4. Zhang, Y., Mu, J., Feng, Y., Kang, Y., Zhang, J., Gu, P. J., ... \& Zhu, Y. H. (2009). Broad-spectrum antimicrobial epiphytic and endophytic fungi from marine organisms: isolation, bioassay and taxonomy. Marine drugs, 7(2), 97-112.

5. Paz, Z., Komon-Zelazowska, M., Druzhinina, I. S., Aveskamp, M. M., Shnaiderman, A., Aluma, Y., ... \& Yarden, O. (2010). Diversity and potential antifungal properties of fungi associated with a Mediterranean sponge. Fungal Diversity, 42(1), 17-26.

6. Saleem, M., Ali, M. S., Hussain, S., Jabbar, A., Ashraf, M., \& Lee, Y. S. (2007). Marine natural products of fungal origin. Natural product reports, 24(5), 1142-1152.

7. Rateb, M. E., \& Ebel, R. (2011). Secondary metabolites of fungi from marine habitats. Natural Product Reports, 28(2), 290-344.

8. Samuel, P., Prince, L., \& Prabakaran, P. (2011). Ocean: the inviolated source of pharmaceutical leads and drug metabolites. World J. Sci. Technol, 1(10), 74-91.
9. Radjasa, O. K., Sabdono, A., Junaidi, J., \& Zocchi, E. (2007). Richness of Secondary Metabolite-Producing Marine Bacteria Associated with Sponge Hatictona $\mathrm{sp}$.

10. Thomas, T. R. A., Kavlekar, D. P., \& LokaBharathi, P. A. (2010). Marine drugs from sponge-microbe association $A$ review. Marine Drugs, 8(4), 1417-1468..

11. Faulkner, D. J. (1997). Marine natural products. Natural Product Reports, 14(3), 259-302.

12. Taylor, M. W., Radax, R., Steger, D., \& Wagner, M. (2007). Sponge-associated microorganisms: evolution, ecology, and biotechnological potential. Microbiology and Molecular Biology Reviews, 71(2), 295-347.

13. Febrianto, R.E. (2014.) Penapisan Aktivitas Antimikroba Bakteridari Spon Laut Haliclona fascigera Asal Perairan Pulau Mandeh Pesisir Selatan Sumatra Barat (Skripsi). Fakultas Farmasi Universitas Andalas.

14. Yu, L. L., Li, Z. Y., Peng, C. S., Li, Z. Y., \& Guo, Y. W. (2009). Neobacillamide A, a Novel ThiazoleLContaining Alkaloid from the Marine Bacterium Bacillus vallismortis C89, Associated with South China Sea Sponge Dysidea avara. Helvetica Chimica Acta, 92(3), 607-612.

15. Proksch, P., Edrada, R., \& Ebel, R. (2002). Drugs from the seas-current status and microbiological implications. Applied Microbiology and Biotechnology, 59(2), 125-134. 